Полішук Н. I., ад'юнкт Львівського державного університету внутрішніх справ ORCID: 0000-0003-3908-2253

\title{
КРИМІНАЛЬНО-ПРАВОВА ХАРАКТЕРИСТИКА МЕДИЧНОЇ ПІДСТАВИ ЗВІЛЬНЕННЯ ВІД ПОКАРАННЯ У ЗВ'ЯЗКУ З ХВОРОБОЮ
}

Інститут звільнення від покарання через хворобу складається з двох самостійних підстав звільнення, медичної і правової. Медична підстава звільнення від покарання ділиться на дві окремі, в залежності від типу настання хвороби (психічна чи інша тяжка хвороба) незалежні одна від одної частини, у зв'язку з психічним розладом (ч. 1 ст. 84 КК України) і в зв'язку з іншою важкою хворобою (ч. 2 ст. 84 КК України).

Ключові слова: звільнення від покарання; тяжка хвороба засудженого; інша тяжка хвороба засудженого; хвороба як підстава для звільнення від покарання.

Институт освобождения от наказания по болезни состоит из двух самостоятельных оснований освобождения, медицинской и правовой. Медицинское основание освобождения от наказания делится на две отдельных, в зависимости от типа наступления болезни (психическая или иная тяжелая болезнь) независимые друг от друга части, в связи с психическим расстройством (ч. 1 ст. 84 УК Украины) и в связи с иной тяжелой болезнью (ч. 2 ст. 84 УК Украины).

Ключевые слова: освобождение от наказания; тяжелая болезнь осужденного; иная тяжелая болезнь осужденного; болезнь как основание для освобождения от наказания.

Постановка проблеми. Звільнення від покарання за хворобою можливе за наявності декількох підстав та обставин. У даній статті виділено обов'язкові кримінальноправові ознаки медичної підстави звільнення, які враховуються судом при звільненні особи від покарання у зв'язку з настанням важкої хвороби та проведений кримінальноправовий аналіз вказаних ознак.

Аналіз останніх досліджень і публікацій. Дослідженням особливостей звільнення від покарання у зв'язку з іншою важкою хворобою займалися свого часу відомі вчені у галузі кримінального права та кримінології, а саме: М. І.Бажанов, Ю. В. Баулін, В. І. Горобцов, О. П. Гоpoх, М.Н. Голоднюк, О.Ф. Ковітіді, А. С. Михлин, А. А. Музика, А. В. Наумов, Ю. А. Пономаренко, М. В. Романов, В. В. Скибицький, М. І. Хавронюк та інші.

Постановка завдання. Метою статті $\epsilon$ аналіз та дослідження медичної підстави звільнення від покарання у зв'язку з іншою важкою 
хворобою та виділення та кримінально-правова характеристика основних ознак медичної підстави звільнення.

Виклад основного матеріалу. Проведений аналіз норми, що передбачає звільнення від покарання у зв'язку з іншою важкою хворобою, дозволив виділити три основних групи ознак, що відносяться до характеристики хвороби як медичної підстави звільнення, а саме важкий характер хвороби, момент їі виникнення та наявність перешкод до відбування покарання.

Розглядаючи першу групу ознак медичної підстави звільнення від покарання у зв'язку з хворобою, таку як важких характер хвороби, то не обхідно зазначити, що медицина не дає визначення поняття «важка хвороба» чи «інша важка хвороба», оскільки медицина оперує іншою термінологією, а саме поняття «хвороба», а також виділяє декілька стадій розвитку хвороби, серед яких до прикладу ускладнення [4, с. 59]. Виходячи з цього, необхідно зазначити, що термін «важка хвороба», що використовується в ч. 2 ст. 84 КК України не являється спеціальним терміном запозиченим із інших наук, на відміну від терміну «психічна хвороба» що передбачений в ч. 1 ст. 84 КК та запозичений 3 судової психіатрії. Поняття «важка хвороба» не можна віднести і до оціночних понять, оскільки вона детально регламентується в Переліку хвороб, які $\epsilon$ підставою для подання до суду матеріалів про звільнення засуджених від подальшого відбування покарання та передбачено в Спільному наказі Міністерства юстиції України та Міністерства охорони здоров'я України «Про затвердження Порядку організації надання медичної допомоги засудженим до позбавлення волі» від 15.08.2014 № 1348/5/572 [5] (далі Перелік). Видається за необхідне віднести досліджуване поняття до банкетних понять, оскільки, якщо поняття «тяжкість захворювання» у випадку звільнення від покарання у зв'язку з хворобою визначається у нормативно-правовому акті, то логічно що при прийнятті нового Переліку зазнає змін і розуміння терміну важка хвороба в цьому контексті, а тому, як зазначає Г. Є. Болдарь, дану норму слід віднести до банкетного поняття, зміст якого може змінюватись услід за зміною тих нормативних актів, які розкривають його значення $[9$, c. 177].

Указаним Переліком керуються спеціальні медичні комісії при огляді засуджених та встановлені категорій захворювань, які можуть бути медичною підставою для звільнення, одночасно адміністрація виправних установ використовує вказаний перелік при поданні матеріалів про звільнення від покарання за хворобою в суд, суди в свою чергу при прийнятті рішення, часто посилається на вказаний перелік в своїх рішеннях [6; 7; 8], оскільки це єдиний нормативно-правовий документ, який регламентує звільнення від покарання за хворобою. Необхідно зазначити, що вказаний Перелік передбачає в якості медичної підстави звільнення тяжкі захворювання в найтяжчих стадії в поєднанні 3 ускладненнями на інші органи або супутніми захворюваннями, основними серед яких є:

- туберкульоз в найтяжчих формах в поєднанні з ускладненнями на інші органи, до прикладу тубер- 
кульоз у стадії ускладнення: прояви легенево-серцевої недостатності III ступеня;

- інфекція вірусу імунодефіциту людини (ВІЛ/СНІД) IV клінічна стадія, що характеризується опортуністичними захворюваннями та станами серед яких, до прикладу такі, як саркома Капоші, токсоплазмоз ЦНС, ВІЛ-асоційована енцефалопатія тощо;

- лепра у лепроматозній пограничній формі або туберкулоїдна та недиференційована форми за наявності поширених проявів на шкірі, наявності мікобактерій із зіскобу 3 носа;

- новоутворення IV стадії за міжнародною класифікацією TNM (3 гістологічним та морфологічним підтвердженнями);

- хвороби ендокринної системи, серед яких Цукровий діабет в важкій стадії з ускладненнями або Синдром Іценка-Кушинга та хвороба ІценкаКушинга з різко вираженими ускладненнями: патологічні переломи;

- хвороби нервової системи та органів чуття, серед яких хвороба Альцгеймера та інші дегенеративні хвороби нервової системи за наявності вираженої деменції або повна сліпота, геміплегії, параплегії, глибокі геміпарези та парапарези 3 розповсюдженими розладами чутливості;

- хвороби органів кровообігу в найтяжчих стадіях;

- хвороби органів травлення, серед яких, до прикладу Цирози печінки, Печінкова недостатність III, IV стадій, та інші;

- хронічні хвороби нирок IV, V стадій;

- хвороби кістково-м'язової системи та сполучної тканини;
- подагра 3 подагричною нефропатією і хронічною хворобою нирок IV, V стадій;

- висока ампутація верхніх або нижніх кінцівок, а також поєднання високих ампутацій однієї верхньої і однієї нижньої кінцівок;

- гостра променева хвороба.

Перелік, як нормативно правовий акт, доволі часто зазнавав змін, так до прикладу з 1992 р. до сьогодення було прийнято три так званих переліки, першим з яких був передбачений в Наказі Міністерства внутрішніх справ № 256 від 13.05.92 «Про порядок представлення в суди матеріалів про звільнення від дальшого відбуття покарання засуджених, які захворіли на тяжку хворобу» [10], далі в 2000 р. у зв'язку з прийняттям спільного наказу Державного департаменту України з питань виконання покарань та Міністерства охорони здоров’я України № 3/6 від 18.01.2000 «Про затвердження нормативно-правових актів з питань медико-санітарного забезпечення осіб, які утримуються в слідчих ізоляторах та установах виконання покарань Державного департаменту України $з$ питань виконання покарань» [11] та чинним на сьогодні Переліком захворювань, прийнятим в 2014 р. Така тенденція обумовлена тим, що в медицині уявлення про невиліковність та хронічних характер окремих захворювань постійно змінюється, що пов'язано з можливостями медицини лікувати хвороби, які раніше не підлягали лікуванню, а також 3 поступовою гуманізацією норм кримінального права. У зв'язку з цим, видається, що використання банкетного поняття цілком виправдане.

Аналіз іншої тяжкої соматичної хвороби як підстави звільнення від 
відбування покарання за Кримінальним Кодексом України (далі КК) дозволяє стверджувати, що відсоткова частка осіб 3 зазначеними захворюваннями значно переважає над психічно хворими особами, які були звільнені на підставі ч. 1 ст. 84 КК України. Так, в результаті проведеного дослідження медичної підстави звільнення у зв'язку з хворобою особам, які підлягали звільненню, були встановлені наступні тяжкі захворювання:: туберкульоз легенів близько 33\%; злоякісні новоутворення різних органів і тканин близько 24\%; цироз печінки різної етіології в стадії декомпенсації близько 12\%; хвороби органів кровообігу - близько 10\%; хвороби нервової системи та органів чуття (в тому числі повна сліпота та інші патологічні зміни зору) - близько 6\%; різні захворювання головного мозку - 5\%; хвороби ендокринної системи (цукровий діабет) - близько 4\%; анатомічні дефекти (висока ампутація верхніх або нижніх кінцівок) близько 3\%; інші важкі хвороби близько 2\% [1]. Результати наведеного дослідження дозволяють говорити, що прогресивний туберкульоз легень був медичною підставу звільнення для кожного третього звільненого за хворобою засудженого, а хвороби пов'язані зі злоякісними новоутровенннями або цироз печінки вірусної етіології були у кожного четвертого засудженого та кожного десятого звільненого, відповідно.

Розглядаючи медичну підставу звільнення, таку як тяжкість захворювання, необхідно зазначити, що нині Україна займає друге місце в Європі щодо захворюваності на туберкульоз, що викликано, головним чином, соціально-економічними по- трясіннями і пов'язаними 3 ними бідністю, зростанням числа безхатченків. Значну роль зіграло загальне зменшення витрат на охорону здоров'я, в результаті чого ефективність заходів з контролю над туберкульозом знизилася, і за останнє десятиліття відзначений небезпечне зростання захворюваності [12, с. 70]. Ще одним небезпечним фактором $\epsilon$ те, що з 1993 по 2018 рр. у пенітенціарних установах України відносна кількість ВІЛ-інфікованих засуджених збільшилася в кілька разів. Частка ВІЛ-інфікованих засуджених від загального числа осіб, які відбувають покарання, складає близько 7\%, що перевищує аналогічний показник по країні майже в 15 разів. Зростає число ВІЛ-інфікованих в поєднані з туберкульозом [13, с. 32]. Як показують дослідження в регіонах, пенітенціарна система України, в цілому, виявилася не підготовленою до такої ситуації. Відвідування ряду установ виявили значну різницю в умови утримання ВІЛ-інфікованих засуджених, що в багатьох випадках пов'язане 3 дискримінацією цієї категорії засуджених. В окремих виправних установах (таких не більше 5\% від загального числа обстежених) інфіковані засуджені утримуються разом з іншими засудженими. Відзначимо, що співробітники саме цих установ при інтерв'юванні показали високий рівень знань про профілактику ВІЛінфекції. Зараження вірусом імунодефіциту $\epsilon$ одним 3 найсерйозніших чинників ризику для розвитку туберкульозної інфекції в активний туберкульоз. Шанси на розвиток інфекції в активну форму захворювання на ТБ серед людей, інфікованих і мікробактерією туберкульозу, і вірусом імунодефіциту у 10 разів вище, ніж у лю- 
дей, інфікованих тільки мікобактерією туберкульозу. У всьому світі туберкульоз $€$ основною причиною смерті людей, заражених вірусом імунодефіциту. ВІЛ-інфекція також прискорює розвиток заразною форми туберкульозу, підвищуючи небезпеку його передачі [14]. Особливу занепокоєність викликає потенційна небезпека масового поширення туберкульозу серед ВІЛ-інфікованих в тюрмах, де показники захворюваності на туберкульоз, у т.ч. МЛС (множинна лікарська стійкість) найбільш високі. Необхідні нові підходи до контролю над поширенням ВІЛ-інфекції, включаючи освітні програми і заходи щодо зниження ризику зараження, постачання місць позбавлення волі стерильними внутрішньовенними шприцами і безкоштовними, анонімно доступними презервативами.

Досліджуючи другу ознаку медичної підстави звільнення від покарання за хворобою, а саме момент виникнення хвороби, необхідно зазначити, що аналіз постанов суду про звільнення від покарання у зв'язку з хворобою свідчить про те, що суди не з'ясовують час виникнення важких хвороб у засуджених, i не ставлять таке питання перед фахівцями. У мотивувальній частині постанови про звільнення через хворобу суди обмежуються зазначенням лише наявності хвороби у засудженого 3 посиланням на відповідний пункт Переліку захворювань [3]. Широке застосування такої практики дозволяє сформулювати питання: чи доцільно взагалі з'ясовувати час настання хвороби і яке це має кримінально-правове значення?

Відповідь на зазначене питання необхідно починати 3 вивчення етіології розвитку важких хвороб у часі. До прикладу, такі захворювання як новоутворення (рак), що є підставою до подання матеріалів до суду про звільнення від покарання засудженого, характеризуються поступовим виникненням і тривалим розвитком. Як зазначають українські науковці, серед яких В.А. Огнев, А. М. Зінчук, рак легенів не має гострого початку, розвиток захворювання повільний. Латентний період може тривати декілька років. Клінічні симптоми з'являються набагато пізніше за виникнення самого захворювання. До розвитку клінічної стадії раку легенів особливих змін в організмі не відбувається. Прихований патологічний процес не дає можливості запідозрити його наявність та клінічне відображення $[15$, c. 36$]$.

Іншою, не менш важливою обставиною $\epsilon$ те, що частина засуджених вперше проходять комплексне медичне обстеження тільки при надходження до виправної установи, де і вперше документально встановлюється діагноз, хоча хвороба у такої особи могла була і до засудження, а можливо і до вчинення злочину.

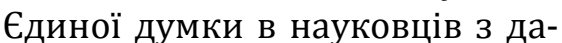
ного питання не має, частина науковців, серед яких, до прикладу Р. А. Базаров, К. В. Михайлов, зазначають, що час виникнення тяжкої хвороби має принципове кримінально-правове значення, оскільки, якщо важка хвороба не завадила вчинити злочин особі, то після звільнення, така хвороба також не завадить вчинити їй новий злочин, тому таку особу не може бути звільнено [16, с. 87]. Інша частина науковців, серед яких, до прикладу О. П. Горох, вважають, що час виникнення хвороби не має кримінально-правового значення та 
не має впливати на можливість звільнення особи від покарання. [17, с. 391]. Формуючи свою позицію 3 даного питання необхідно зазначити, що чинний перелік передбачає також звільнення для осіб, які захворіли до засудження, але їх хвороби внаслідок прогресування набули характеру, зазначеного в переліку хвороб [18], про це ж говорить і Постанова Пленуму Верховного Суду України № 8 від 28.09.73 «Про практику застосування судами законодавства про звільнення від відбуття покарання засуджених, які захворіли на тяжку хворобу» [19]. Виходячи 3 цього, вважаємо за необхідне підтримати ту частину науковців, які стверджують, що час настання тяжкої хвороби не має кримінальноправого значення.

Аналіз такої групи кримінально-правових ознак, як наявність перешкод до відбування покарання в контексті звільнення від покарання у зв'язку з хворобою, нами виділено в окреме дослідження, зміст якого дозволив стверджувати, що умови та порядок тримання засуджених $\mathrm{y}$ звичайних (нелікувальних) виправних установ підтверджує, що важка хвороба перешкоджає реалізації карально-виправних заходів в установах, не призначених для застосування заходів медичного характеру (лікувального впливу) стосовно тяжкохворих засуджених. Зазначений висновок в цілому розповсюджується на покарання у виді позбавлення волі та арешту, при відбуванні якого засуджений також знаходиться в умовах суворої ізоляції від суспільства [2].

Висновки. Таким чином, кримінально-правовий аналіз медичної підстави звільнення від покарання у зв'язку 3 іншою важкою хворобою дозволив виділити три основних групи ознак 3 яких складається медична підстава звільнення, серед яких: важкий характер хвороби, момент їі виникнення та наявність перешкод до відбування покарання. Проведене дослідження дозволило провести характеристика кожної 3 цих підстав.

\section{Список використаних джерел}

1. Дані про тяжкі хвороби, отримані в результаті вивчення 104 рішень суду, звільнених за ст. 84 КК України за період з 2016 по 2020 рр. в Україні, взятих з відкритої бази «Єдиний державний реєстр судових рішень».

2. Поліщук Н. І. Повторне звільнення від покарання в зв'язку з хворобою. Інтеграція освіти, науки та бізнесу в сучасному середовищі: зимові диспути: тези доповідей I Міжнародної науково-практичної інтернет конференції, 6-7 лютого 2020 р. Дніпро, 2020. Т. 3. С. 37-40.

3. Такий висновок зроблено на основі вивчення рішень, ухвалених судами першої інстанції м. Миколаєва та Миколаївської області за період з 2011 по 2016 pp. URL: https://mka.court.gov.ua/sud1490/pokazniki-diyalnosti/uzagal_sud_praktik/analise_5 (дата звернення 01.12.2020).

4. Покровский В. И. Популярная медицинская энциклопедия. Издание 3-е, переработанное и дополненное. Москва : Издательство Советская Энциклопедия, 1991. $668 \mathrm{c.}$

5. Спільний наказ Міністерства юстиції України та Міністерства охорони здоров'я України «Про затвердження Порядку організації надання медичної допомоги засудженим до позбавлення волі» від 15.08.2014 № 1348/5/572. URL: https://zakon.rada.gov.ua/laws/show/z0990-14 (дата звернення 06.12.2020). 
6. Ухвала Снігурівського районного суду Миколаївської області від 10 червня 2019 року Справа №485/866/19 Провадження № 1-в/485/67/19 URL: https://zakononline.com.ua/court-decisions/show/82311119 Здата звернення 02.12.2020).

7. Ухвала Жовтневого районного суду м. Запоріжжя від 23 березня 2020 року Провадження № 1-в/331/39/2020, Єдиний унікальний номер 331/1015/20 URL: https://opendatabot.ua/court/88366906-efe33fa2b6d181baf70671a158b6430e (дата звернення 01.12.2020).

8. Вирок Олександрійського міськрайонного суду Кіровоградської області від 24 лютого 2020 року Справа №: 398/270/20, провадження № 1-кп/398/242/20. URL: https://opendatabot.ua/court/87778048-5f2f82fa30ac24629262b988ed0e7e85 (дата звернення: 03.12.2020).

9. Болдарь Г. Є. Бланкетність як форма міжгалузевих зв'язків кримінального права. Науковий вісник Міжнародного гуманітарного університету. Серія Юриспруденція. 2014. №7. С. 176-179.

10. Наказ Міністерства внутрішніх справ N 256 від 13.05 .92 року «Про порядок представлення в суди матеріалів про звільнення від дальшого відбуття покарання засуджених, які захворіли на тяжку хворобу» URL: https://zakon.rada.gov.ua/ rada/show/v0256320-92\#Text (дата звернення 03.12.2020).

11. Спільний Наказ Державного департаменту України з питань виконання покарань та Міністерства охорони здоровя України N 3/6 від 18.01.2000 року "Про затвердження нормативно-правових актів з питань медико-санітарного забезпечення осіб, які утримуються в слідчих ізоляторах та установах виконання покарань Державного департаменту України 3 питань виконання покарань. URL: https://zakon.rada.gov.ua/rada/show/z0143-00\#Text (дата звернення 02.12.2020).

12. Шатковська Д. М. Адміністративно-правове регулювання організації охорони здоров'я при соціально-небезпечних захворюваннях: дисертація на здобуття наукового ступеня кандидата юридичних наук. Київ, 2016. 215 с.

13. Балакірєва О. М., Бондар Т. В., Аналітичний звіт за результатами кабінетного дослідження «Секторальна політика України 3 попередження поширення ВІЛінфекції серед засуджених та осіб, що взяті під варту», Управління ООН з наркотиків і злочинності (UNODC) в Україні. Київ, 2012. 68 с.

14. Harries AD, Mäher D. TB/HIV: A clinical manual. WHO/TB/96.200. WHO; Geneva, 1996.

15. Огнєв В. А, Зінчук А. М. Визначення чинників, що впливають на розвиток раку легенів, та сили їх впливу на організм людини. Здоров'я населення: тенденції та прогнози. Вісник соціальної гігієни та організації охорони здоров'я України. 2015. № 2 (64). C. 36-40.

16 Базаров Р. А., Михайлов К. В. Освобождение от уголовной ответственности и наказания. Учебное пособие. Челябинск : ЧЮИ МВД РФ, 2001. 378 с.

17. Горох О. П. Звільнення від покарання та його відбування за кримінальним правом України: дисертація на здобуття наукового ступеня доктора юридичних наук. Київ, 2019. 697 с.

18. Спільний наказ Міністерства юстиції України та Міністерства охорони здоров'я України «Про затвердження Порядку організації надання медичної допомоги засудженим до позбавлення волі» від 15.08.2014 № 1348/5/572. URL: https://zakon.rada.gov.ua/laws/show/z0990-14 (дата звернення: 02.12.2020).

19. Постанова Пленуму Верховного Суду України № 8 від 28.09.73 «Про практику застосування судами законодавства про звільнення від відбуття покарання засуджених, які захворіли на тяжку хворобу» URL: https://zakon.rada.gov.ua/ laws/show/v0008700-73\#Text (дата звернення: 02.12.2020). 


\section{References}

Pokrovsky, V (1991). Popular Medical Encyclopedia. 3rd edition, revised and supplemented. Moscow [in Russian].

Boldar, G. (2014). Blanket as a form of intersectoral relations of criminal law. Scientific Bulletin of the International Humanities University, Jurisprudence series, 7, 176-179 [in Ukrainian].

Shatkovska, D. M. (2016). Administrative and legal regulation of the organization of health care at socially dangerous diseases (Dissertation on competition of a scientific degree of the candidate of legal sciences). Kyiv [in Ukrainian].

Ognev, V.A., Zinchuk, A. M. (2015). Determining the factors influencing the development of lung cancer and the strength of their impact on the human body. Population health: trends and forecasts. Bulletin of social hygiene and health care organization of Ukraine, 2 (64), 36-40 [in Ukrainian].

Bazarov, P. A., Mikhailov, K. B. (2001). Exemption from criminal liability and punishment. Chelyabinsk: CHUI Ministry of Internal Affairs of the Russian Federation [in Russian].

Gorokh, O. P. (2019). Exemption from punishment and its serving under the criminal law of Ukraine. (The dissertation on competition of a scientific degree of the doctor of legal sciences). Kyiv [in Ukrainian].

\section{N. Polishchuk, Adjunct of Lviv State University of Internal Affairs} ORCID: 0000-0003-3908-2253

\section{Criminal law description of the medical grounds for exemption from punishment due to illness}

The institution of exemption from punishment due to illness consists of two independent grounds for exemption, medical and legal. The medical basis for release from punishment is divided into two separate, depending on the type of disease (mental or other serious illness) independent of each other, in connection with a mental disorder (Part 1 of Article 84 of the Criminal Code of Ukraine) and in connection with language with another serious illness (Part 2 of Article 84 of the Criminal Code of Ukraine). The legal basis for exemption from punishment for illness is the inexpediency of serving a sentence for seriously ill convicts and it is impossible to achieve the corrective goal of punishment for the mentally ill. Speaking about the medical grounds for dismissal in connection with another serious illness, it should be noted that the analysis of the content of Part 2 of Article 84 of the Criminal Code of Ukraine, which provides for release from serving a sentence in connection with another serious illness, allows to distinguish three groups of signs, relating to the characterization of this disease as a medical basis for dismissal. One of the main ones is that the convict's serious illness should be included in the list of diseases that can serve as a basis for exemption from punishment for the disease, the severity of the disease. The second important group of signs is the time of occurrence of such a disease - before the crime, after the crime or sentencing. The next important group of signs is the presence of obstacles to serving a sentence.

Keywords: release from punishment; serious illness of the convict; other serious illness of the convict; illness as a ground for release from punishment. 